Article

\title{
An Adaptation of SERVQUAL for Events Evaluation: An Environmental Sustainability Addon
}

\author{
Andromeda Menezes ${ }^{1,2, *}$, Rui M. Lima ${ }^{2, *(1)}$, André Luiz Aquere ${ }^{3, *}$ and Marlene Amorim ${ }^{4, *(1)}$ \\ 1 Federal Institute of Espirito Santo, Campus Cariacica, Cariacica 29150-410, Brazil \\ 2 Algoritmi Center, Department of Production and Systems, School of Engineering, University of Minho, \\ 4800-058 Guimarães, Portugal \\ 3 Department of Civil and Environment Engineering, Faculty of Technology, University of Brasilia, \\ Brasília 70910-900, Brazil \\ 4 GOVCOPP, Department of Economics, Management and Industrial Engineering and Tourism, \\ University of Aveiro, 3810-193 Aveiro, Portugal \\ * Correspondence: andromeda@ifes.edu.br (A.M.); rml@dps.uminho.pt (R.M.L.); andre@unb.br (A.L.A.); \\ mamorim@ua.pt (M.A.)
}

Received: 20 August 2020; Accepted: 3 September 2020; Published: 9 September 2020

\begin{abstract}
The events sector is continuously growing, driven by economic development and increased spending on leisure. As events may generate a large amount of waste, an environmental impact assessment is increasingly important for any event. The importance and necessity of this has recently become more significant not only from an environmental preservation perspective, but also from a social responsibility perspective, and from a marketing and public relations perspective. This paper presents a study carried out with the objective of creating a model adapted from the ServQual to evaluate the quality of the service provided with events, complementing the model with an environmental sustainability add on. Based on an action-research approach, a model was built that was developed and applied to small events in a Brazilian municipality. As the main result of this work, this approach allowed to create a way to measure the event quality, considering the gaps between expectations and perceptions of the client, adapting the ServQual Model to an event-type service. Moreover, it allowed the inclusion of an environmental sustainability dimension to ServQual. This adaptation of the model introduced new managerial analysis and was considered relevant by event managers. This study extends the application of service management tools to the specific domain of events, building on the perspective that event management shares a great deal of characteristics of services.
\end{abstract}

Keywords: event management; sustainable events; project management; environmental sustainability; service quality; ServQual

\section{Introduction}

In recent years we have observed a growing concern with the sustainability of human practices across all sectors of activity [1]. The area of event management is no exception given the wide range of economic and environmental impacts that can be derived from them [2].These refer not only to the impacts associated to the activities that take place in the event dates, but also to all the logistics and other related activities that surround event organization and access. The case of mega events (e.g., world's championships, festivals, etc.) offers good illustrations about the range and the intensity of the impacts that can be associated with this industry [2]. In addition, according to Turner and Kennell [3], as the use of historic buildings as spaces for events grows, professionals in this area, who work in historic buildings, face a series of sustainability challenges, including conservation, preservation, social value 
and financial sustainability, as well as customer satisfaction. For the authors, few studies have yet been carried out in this context. Another approach that has shown a concern regarding the environmental impacts of events is the increase in the number of festivals that directly influence the increase in event tourism [4]. The authors argue that event tourism must encourage sustainable travel, and that festival organizers should consider a wide range of factors that are unique to festivals and their geographic locations, whereas: (1) there is a need for sustainable tourism development due to the growth of the tourism industry worldwide and the adverse effects of tourism on social structure, natural resources, and cultural values; (2) sustainable tourism allows us to reduce the environmental impact and maximize the social and economic advantages of tourist destinations; and (3) sustainability must consider both the development and the preservation of the tourism industry. Kişi [5] developed a study that considers that tourism activities need to be carefully planned, managed, and monitored, using a long-term sustainable approach. Thus, the author brings a strategic approach to the development of sustainable tourism in destinations, presented through the application of the A'WOT (AHP-SWOT) hybrid method, developed in combination with SWOT (Strengths, Weaknesses, Opportunities, Threats) analysis and the AHP (Analytic Hierarchy Process) method.

Despite these evidences, the literature addressing green impacts and sustainability in the event sector is still rather scarce and does not offer enough knowledge to inform managerial decisions on this regard. This study offers a contribution for the advance of the knowledge on the sustainable organization and management of events.

Based on this problem, the following research question arises: How to verify the quality of the event from the client's expectations and perceptions, considering environmental issues?

This study builds on the perspective that event shares a great deal of characteristics of services, and, as such, it extends the application of service management tools to the specific domain of events. Thus, it is possible to use existing models for the measurement of service quality as a basis for developing instruments to assess the quality of events considering an environmental sustainability dimension.

Celebration and leisure activities are social expressions, of a private or public nature, and materialized through events. These activities date back to the beginnings of humanity, and have takenon an increasing expression in societies, as cultural elements that, very often, break routine and generate social benefits including personal satisfaction, individual, and social identity, as well as impacts at the social level, inclusion, interculturality, and well-being in general. The organization of events has an important economic expression, representing, particularly since the 1990s, a substantial and growing weight in the creation of value and employment, motivated by economic development and which has resulted in increases in spending on leisure [2,6].

The "CWT Meetings \& Events trend report" (Carlson Wagonlit Travel) [7], in its Eighth Annual Meetings and Events Trends Report, informs that worldwide, the events sector is estimated at 748.79 billion Euros (considering the exchange rate 22 June 2020) and continues to grow. According to CWT, the world is going through a moment of innovation in technology, economic investment, and advances in sustainability. Despite some signs of economic uncertainty surrounding some of the main European markets and the potential instability caused by the UK's withdrawal from the European Union, in general, the sector has been growing. Regarding the larger markets, CWT said in its report that the US, Europe, and Asia are driving most of that demand. In addition, there is an expectation that emerging markets, such as India and China, will grow more intensely in the coming years, as populations are motivated by travel, events, and personal development.

The Allied Market Research [8], on "Global Opportunity Analysis and Industry Forecast 2019-2026", informs that the global events industry size was valued at 1100 billion USD in 2018, and is expected to grow at a Compound Annual Growth Rate (CAGR) of $10.3 \%$ to reach 2330 billion USD by 2026. Events refer to public gathering of populace at a determined time and place.

The growing interest and economic impact of events makes it important to develop knowledge about the management and organization of events that can guide the work of managers in improving their performance $[2,6,9]$. The improvement of events' performance comprises several dimensions, 
namely its legacy and impacts on society, as the type of activities in this sector is characterized by a great involvement of the community, offering consequences for the visibility and positioning of the territories, including the encouragement of tourism activities, while seeking, increasingly, to minimize their negative impacts in environmental terms $[2,10]$.

\section{Conceptual Background}

The event production has increased in recent years due to the need for cities to promote tourism, to improve the local economy, or to improve their visibility. This chapter talks about the causes of this growth, shows how events have been impacting the environment and highlights the need to develop a systematic way of evaluating these events, in order to improve their quality, add value to the customer, and generate more positive impacts and less negative impacts to the environment.

\subsection{Service Management}

A service is a change in the condition of a person, or a property belonging to an economic entity, resulting from the activity of some other economic entity, with the approval of the first. Service is also understood as a provider-customer interaction that creates and captures value [11]. Other definitions of services emphasize an exchange between two or more parties and a (potentially intangible) transformation received by a customer. Services differ from consumer goods in that they are generally unique; intangibles; knowledge-based (educational, medical, legal, among others) which makes them difficult to automate; they are produced and consumed simultaneously; its production has high interaction with the client; may be highly flexible and therefore often inconsistent [11,12]. Sampson [13] offers a useful perspective describing services as bidirectional supply chains whose operations and value creation build on interactions and exchanges between the customer and the provider.

It should also be understood that, in services, there is a distinction between inputs and resources, where the inputs are the consumers themselves, and the resources are the facilitating goods for the execution of the service. Resources integrate employee work and capital and can be somehow controlled by the service manager. Customer participation is a fundamental characteristic of services [14], in such a way that Amorim, Moscoso, and Lago [15] state that "the delivery of services always requires some type of interaction with the customer".

According to Zeithaml et al. [16], the differences between goods and services are based on four fundamental aspects: intangibility, heterogeneity, simultaneity, and perishability. Table 1 presents the characteristics of the services and its implications.

Table 1 presented the characteristics of the services and its implications. Several authors have been working on ways to mitigate some of the difficulties posed by the intrinsic characteristics of services. Regarding the difficulties to assess the quality of services, there are examples that report the importance of word-of-mouth in services as an important and reliable source of information in order to mitigate the difficulties of service (pre) inspection. An example of such a study in the events sector can be found in Dowell [17].

Despite the fact that intangibility is a key feature of services, several studies advocate for the development of tangible clues in order to reinforce the benefits of services on the eyes of the customer [18].

Dealing with Heterogeneity and Simultaneity may pose specific constraints to service delivery and quality assessment, which are addressed by Koc, Ulukoy, Kilic, Yumusak and Bahar [19], researching customer participation and its potential for failure, as well as on the attribution of existing quality deficiencies.

Finally, literature in the field has advanced some strategies to mitigate the implications of perishability, notably overbooking practices. The usefulness and the potential impacts of such strategies are also discussed. See for example the work by Guo, Dong, and Ling [20]. 
Table 1. Service characteristics and implications.

\begin{tabular}{l} 
Service Characteristics \\
\hline Intangible elements \\
The delivery of services includes many intangible \\
elements that are important for value creation and \\
satisfaction on the eyes of the customer. In many \\
services experiences, customers value and assess \\
elements such as comfort, trust, fun, wellbeing. \\
These are hard to visualize and to measure/asses in an \\
objective manner.
\end{tabular}

The presence of intangible elements has several consequences for the production and quality assessment of services. These difficulties include, for example:

- The complexity it offers for customers to be able to inspect the quality of a service.

- The difficulties in assessing and measuring some results of the service experience.

- The heterogeneity of perceptions experiences across different customers for a given service.

\section{Heterogeneity}

The combination between the intangible nature of the service and the customer's participation in the production of the service, makes the provision of customer service to customer variable, generating heterogeneity.
The fact that a service is intangible, the observation of the standard and even the interpretation in this sense implies:

- Difficulties in standardizing the service.

- The quality of services becomes dependent on several uncontrollable factors.

- $\quad$ The quality of services is difficult to measure.

Another implication is the fact that intangible attributes can allow for a stronger differentiation of service offerings and making them more difficult to copy and creating a source of competitive advantage.

The fact that production and consumption happen simultaneously implies:

\section{Simultaneity}

The services production and consumption occur simultaneously.
- Diminishes the opportunities for intervention in the quality control process.

- $\quad$ Exposes the production system to customer participation and impact in operations and quality.

The fact of being perishable, implies in:

\section{Perishability}

The services are seen as non-stocking, that is, the service is not stocked since the customer's presence is indispensable in the process of providing the service.
- "if not used, it will be lost".

- The total use of the capacity of a service is a challenge for management, considering that the variation in customer demand is considerable, due to the fact that there is no possibility to create stocks to absorb these fluctuations.

The implications for services, of each of the peculiar characteristics to the events, described in this table, are decisive factors for the effective processes of management and evaluation. Services cannot be seen or touched, but the quality of its results will directly impact its position within a competitive market.

\subsection{Service Process}

For the service provision, it is important to understand its process, which can be mapped into a set of activities necessary for the delivery of the service. Many different methodologies have been proposed in the literature, which generally suggest different ways of structuring the process phases. According to Bitran and Lojo [21], widely used, the activities of a service can be organized as follows: 1-access to the service; 2-check-in and diagnosis of customer needs; 3 - execution of the main provision of services; 4-leaving the client and; 5-monitoring and customer feedback, which may include quality control.

The logical sequence of the phases may change; some may occur simultaneously or, eventually, not. This will happen according to the service [15]. The author states that the degree of customer participation changes over a service process according to these phases. In addition, some phases of the service require a minimum level of customer participation. In others, like the access and exit phase, 
some active participation by customers is always necessary to access the service or the service interface channel (e.g., telephone or web services). In the diagnostic phase, some customer information will always be needed to identify the customer's needs. The company may have different alternatives to collect this information with greater or lesser participation from the customer. During delivery and quality control, however, companies are free to decide the type and degree of customer participation. A second reason to differentiate phases is that the customer's perception of value may be different in each of them, since the activities carried out may affect different dimensions of the perceived value. For example, during delivery and follow-up, perceptions may depend on customers' degree of control over the final results.

Still according to Amorim et al. [15], for each type of service, consumers can act in a different way. For example: in service design, clients often act as consultants, contributing with labour and know-how. Likewise, in marketing and sales services, the customer can act as a promoter. Finally, after delivery of the service, customers can act as agents for improving the service, providing explicit suggestions, or acting as an indirect quality control for the behaviour of other customers.

\subsection{Service Quality}

The assessment of quality in services builds, to a great extent from customer perceptions and judgments. Over the years, the service quality literature in the service field has advanced with models and scales for the measurements of quality that build on information provided by customers about their experiences. One of the early models that has shaped the knowledge and the approaches in the field is the ServQual model, advanced by Parasuraman et al. [22]. One of the key principles of this quality assessment model is the conceptualization of quality as a gap that results from the combination of customers perceptions and expectation about the delivered service. In other words, customers build on expectations about the characteristics and the attributes of the service experience, building on sources of information offered by the companies, the media, and, as mentioned before-due to the intangibility of extensive parts of the service results-also from information provided by other costumers about their own experience. During the service delivery, customers build perceptions about the results received and about all aspects of the service process, including the service atmosphere and all the interactions with the elements of the service system. It is against these perceptions that are personal and naturally subjective that they compare the preformed expectations to end up with final appreciation of what they experienced.

This gap model has inspired the literature about service quality over the years, being natural to apply to the events sector. Experiences are becoming increasingly important in events and festivals, which are prime manifestations of the experience economy and some authors have developed research in this area, bringing evidence about the quality of services [23-25].

\subsection{ServQual Scale}

"The ServQual scale emerged from a series of qualitative and quantitative studies, resulting in a set of five dimensions consistently pointed out by customers as being fundamental to the quality of services" [26]. ServQual is one of the most widely accepted scales to develop appropriate quality of service measures $[22,27]$. In line with the expectation-confirmation paradigm, the ServQual scale considers service quality as a function of the gap between the customer's initial expectations and the perceptions derived from the service delivery experience.

There are 22 items distributed in 5 dimensions considered for evaluation: Tangible Aspects, Reliability, Assurance, Empathy, and Responsiveness. Tangible aspects measure quality from the infrastructure, through the equipment used, and the appearance of the employees. Reliability assesses your company's ability to perform the service reliably, accurately, and according to what was promised to the customer. The Assurance, on the other hand, is the competence of your organization to transmit trust and security to customers. Empathy measures how much customer service can be personalized and individualized according to your needs. In addition, your team must be sensitive to understanding 
the best way to treat your customer, as this will impact their perception of the service provided. Finally, the responsiveness assesses how quickly your company can provide your service and what is your willingness to resolve customer questions.

The ServQual scale is performed in two stages. In the first stage, customers' expectations of the service to be provided are measured, where the expectation of a service is the level of service that the customer believes it should receive from the service provider. In the second stage, customers' perceptions of the performance of the service provided are measured. In both the first and second stages, expectation and perception are considered in relation to each of the 22 items related to the dimensions mentioned above. The evaluations, in general, are carried out through the application of questionnaires (one for each stage), using the Likert scale of 7 points, whose extremes are considered as follows: value 1 for Totally Disagree, and value 7 for I Agree Totally. After applying the questionnaires (step 1,-expectation, and step 2-perception), for each item, the difference between the score for perception and expectation is verified. An item with a negative gap indicates that the performance is below expectations; that is, for this item the result was unsatisfactory for the customer. On the other hand, an item with a positive gap means that the service provider is offering a service that exceeds the customer's expectation, referring to this item. And if the difference is zero, it means that the result expected by the customer is in accordance with the service provided by the supplier.

\subsection{Quality Assessment in Event-Type Services}

According to Slack, Chambers, and Johnston [28], there is a certain science that goods and services provided to the customer with high quality can be turned into a competitive advantage for the company, as they add quality to the good and the provision of the service reduces the rework, the waste, and the return of products within the organization, and, above all, quality motivates consumer satisfaction.

The event is a service, resulting from the execution of a project. And like any other service, it requires quality in its execution. The growing demand for events, starting from the needs of governments around the world to leverage tourism and consequently economic growth, is evident. However, quality from the point of view of the consumer and the provider of this service is essential to achieve the expected results. In a current globalized market, in which goods and services companies are at the mercy of fierce competitiveness, quality in services emerges as a differential for gaining advantages. In this scenario, the service industry, in turn, tends to focus on the needs and expectations of its customers, especially because the products generated by services are concepts and ideas, not objects [29].

Service quality is not easy to measure, so there is a real interest from researchers in the search for the ideal model for assessing service quality. Although there is no consensus on an ideal model, it is admitted that the existing models are good starting points, with a safe, valid, and practical measure for assessing quality in services. With the advent of new information and communication technologies, many companies from different service sectors have invested in new technological interfaces to transfer part of the operations to customers, in order to improve their productivity and quality of service [30].

The current consumer has a variety of ways to find out about a particular service. From the moment he/she has a need, he/she seeks to identify and compare options, and analyse the advantages and disadvantages to finally decide [31]. Knowing what customers expect is an important factor to shape the actions of organizations so that they achieve the required quality in their services. Research on customer expectations, perceptions, and satisfaction is essential to understand and measure the performance of services [32]. The company that does not do this type of research may find it more difficult to understand its customers. Those who do understand customer expectations have the information required to adapt to the constantly changing needs of their customers [16].

The inherent characteristics of the events make the difficulty in measuring the quality of the service. Service quality is not only based on meeting the needs of customers and delivering them efficiently, but, moreover, on creating a rewarding atmosphere and experience. Service quality is important and does not depend on the market segment, because even low-cost services and those 
that reach fewer demanding consumers are vulnerable to competition. This is because the customer generates a pattern in his mind, which forms a basis for comparison between the various alternatives, regardless of the type or value of the service provided. In addition, the inherent characteristics of the service make the flow of activities of the service difficult to standardize and automate in an efficient way [16]. Consequently, waste within the production process of a service, whether in the form of rework, operating time, or disposal of inputs, becomes a major factor for non-compliance with deadlines, expected costs, or expected experience.

Evaluating events is not an easy task for event organizers, since they need to balance the needs and interests of different groups of stakeholders, with the limitations of time and other resources. However, it is important to reflect on the event's processes and results, seek continuous improvement, and provide feedback to stakeholders [33]. The complexity of the assessment is linked to the scope, size, and scale of the event, goals and objectives, and the variety of stakeholders involved. However, while it is easy to broadly outline what is needed, event evaluation is complex with a multitude of barriers, including skills, time, access, and resources [34].

The evaluation of an event is essential either for ensuring its quality and for its management. In addition to obtaining arguments to later use them to publicize and join new participants, the evaluation allows for continuous improvement and an increase in the reputation of this industry. The fact of having guaranteed quality gives credibility to the work done by the company and its professionals. For Kowalik and Klimecka-Tatar [35], the output must be controlled and measured, and the results are the basis for continuous improvement.

Researches on service quality are becoming increasingly important in events and festivals. In terms of sporting events, some research developed on measurement scales allow service quality perceived by the spectator to be evaluated. Armbrecht [23] conducted a study that focuses on the perceived quality of participatory experiences at events, addressing the following question: What are the important aspects of the experience at events? The objective was to develop and refine a scale to measure the quality of the event experience for the runners of a participatory event. The objective of this study was to combine, apply, test, and refine the existing scales to increase the understanding of the perceived quality of events among amateur athletes. The affective and cognitive dimensions are included in the scale. Biscaia et al. [24], developed a model that examines the relationship between quality of service and perceived value of the 2014 FIFA World Cup in Brazil, controlling consumers' opinions about the event in the country. Additionally, consumers' favourable opinion about hosting the event showed a positive effect on both hedonic and utilitarian value. Jin et al. [36] proposed a four-dimension framework comprised of game quality, interaction quality, outcome quality, and physical environment quality. These findings suggest the need for an appealing ambiance and crowd vigilance to enhance the event's value. In his article, Richards [25] applied the Event Experiences Scale (EES) to seven cultural events in different countries, with the aim of identifying generic dimensions of the experience in events. The Analysis indicated the presence of four dimensions of the experience: cognitive impairment, affective impairment, physical impairment, and novelty. Meleddu et al. [37] conducted a study in which it explored the gap between consumer expectations and real satisfaction at cultural events, in which a principal component analysis identifies a set of orthogonal factors related to visitor expectations and real satisfaction. An et al. [38], on the other hand, carried out a study comparing the differences between local and non-local participants in their perceived quality of service at an event, examining the relationships between quality of service, satisfaction, and behavioural intent and exploring the role of residence status of the participants in these relationships.

\subsection{Quality Assessment in Events—Environmental Sustainability Dimension}

Some studies were developed in the context of including sustainability in events evaluation, such as METER (Measuring Events through Environmental Research) [39]. This study uses nine major operational categories, divided into subcategories and detailed items, which cover all the main aspects related to the environmental sustainability of an event and are evaluated in all its phases: planning, 
organization, implementation, and post-event. Pelham [40] discusses in his study the current demand for sustainability in the event industry, in which the entire group of event professionals interviewed agreed that in a short time the demand for sustainability will grow, making this an attractive business model. According to Negrusa et al. [41], it is imperative that stakeholders study the impact of the event in a region. In his research, he examined the economic, socio-cultural, and environmental impact of the International Film Festival of Transylvania (TIFF), considering that the growth of the event had unmistakable and important effects on the city. Events industry plays an important role in current economy and can have a substantial impact for a successful business; in addition, sustainability-oriented tourism is becoming an important component of development and planning of a tourist destination. In his study, Aguiar-Quintana [42] aimed to determine the level of sustainability of three sporting events and compare them with each other according to the areas of prominence, as well as drawing attention to the importance of organizing sporting events aimed at sustainability and minimize its negative effects. And finally, but not exhausting the existing research in the area, in order to assist the stakeholders of the events to develop better practices for managing environmentally sustainable events (green events), contributing to the transformation of society and increasing the quality of life, Ahmad et al. [43] propose that initiatives be carried out in the following areas, called independent variables: energy efficiency, waste minimization, water consumption, and ecological procurement (eco-procurement).

\section{Research Methods}

In a context where events happen more frequently in the daily lives of the population and in the economic strategies of governments around the world, there is a need to treat them as a discipline that must be studied. This is mainly because, with the increase in the demand for events, a consequent environmental impact from them and a greater demand by the population for sustainability, the quality assurance processes of an event must be standardized and continuously revisited.

\subsection{Research Design}

As justified and stated in the introduction, the following research question is the main driver for this study: How to verify the quality of the event from the client's expectations and perceptions, considering environmental issues?

The research question reflects the motivation to develop this study, which seeks to contribute to improving the quality of events, making them increasingly environmentally sustainable.

To answer this question, we chose to use the action-research methodology, as it has a peculiar characteristic, which is the immersion of the researcher in the investigation process, contributing for the improvement of the organization/environment where the research takes place. The methodological approach used in this research design is qualitative. Therefore, this research was structured in stages, in a growing spiral of action-research, in which the following objectives were identified and implemented: Carry out a review of the existing bibliography on the subject; define the variables to be considered in an environmentally sustainable event; define a way to assess the quality of an event from the customer's perspective; apply the defined model; evaluate the model.

The previous stages of research were implemented in several phases. Table 2 presents a summary of the phases, their interrelation, and the main product resulting from each phase.

\subsection{Study Context and Participants}

The Municipality of Vitoria in Espírito Santo, located in south-eastern Brazil, currently has about 360,000 inhabitants, distributed over $97 \mathrm{~km}^{2}$. Since 2018, Vitoria has been a member of Local Governments for Sustainability (ICLEI), and since 2015 it has been part of the Emerging and Sustainable Cities Initiative (ICES). As part of these, the municipality aims to become a more prominent city regarding climate change and air and water pollution improvement. In addition, the Municipality's Sustainability Plan includes several investment projects for the proper development of the capital, 
focusing on three main dimensions: environmental and climate change; urban, which comprises mobility, economic and social development, and security; and, still, the fiscal and governance dimension. It was in this context, to bring a contribution to the municipality of Vitoria, with a focus on environmental sustainability, that this investigation took place, with the author as the intervener in events that took place in the municipality.

Table 2. Research phases.

\begin{tabular}{|c|c|c|c|c|}
\hline $\begin{array}{l}\text { Phases } \\
\text { When? }\end{array}$ & $\begin{array}{l}\text { Methods } \\
\text { How? }\end{array}$ & $\begin{array}{l}\text { Participants } \\
\text { Who? }\end{array}$ & $\begin{array}{l}\text { Empirical Study } \\
\text { What? }\end{array}$ & $\begin{array}{l}\text { Goals } \\
\text { Why? }\end{array}$ \\
\hline Phase 1 & $\begin{array}{l}\text { Literature } \\
\text { revision }\end{array}$ & Authors & $\begin{array}{l}\text { Review the existing } \\
\text { bibliography about the } \\
\text { themes of study. }\end{array}$ & $\begin{array}{l}\text { Understand existing models } \\
\text { for assessing service quality. } \\
\text { Define the dimensions that } \\
\text { characterize an event as } \\
\text { environmentally sustainable. }\end{array}$ \\
\hline Phase 2 & Synthesis & Authors & $\begin{array}{l}\text { Define a way to evaluate } \\
\text { the quality of an event } \\
\text { from the customer's } \\
\text { perspective. }\end{array}$ & $\begin{array}{l}\text { Develop an adaptation of } \\
\text { ServQual to evaluate events. }\end{array}$ \\
\hline \multirow[t]{2}{*}{ Phase 3} & Questionnaire & Public $=31$ & $\begin{array}{l}\text { Study on the perception } \\
\text { and expectation of the } \\
\text { participant of an event in } \\
\text { relation to the service } \\
\text { provided in the city of } \\
\text { Vitoria-ES. }\end{array}$ & $\begin{array}{l}\text { Application of the Model for } \\
\text { evaluating the quality of } \\
\text { events, from the user's point } \\
\text { of view. }\end{array}$ \\
\hline & Focus Group & Experts $=4$ & $\begin{array}{l}\text { Qualitative study on the } \\
\text { applicability of the } \\
\text { proposed model. }\end{array}$ & $\begin{array}{l}\text { Qualitative evaluation of the } \\
\text { model for evaluating the } \\
\text { quality of events proposed } \\
\text { by experts. }\end{array}$ \\
\hline
\end{tabular}

The participants of events, which were part of the research, were a total of 31, between men and women, and were distributed in 3 (three) events studied. The participation of these people in the investigation occurred in order to validate the inclusion of Sustainability as a quality parameter of an event.

The researchers used an adapted ServQual questionnaire quality assessment model for data gathering and focus group for evaluation of that quality assessment model. The questionnaire was developed by adapting the existing questions to events and by defining new variables for the environmentally sustainability dimension. These questions and variables evolved from the analysis of the literature, the immersive experience in event management, and the discussions between the researchers. In this approach, the researchers adopted a positioning of developing the questions, supported with the existing knowledge, from inside the organizations and for the organizations, which is coherent with the action-research paradigm [44].

Aiming to evaluate the model, the researchers adopted the positioning of evaluating it with stakeholders with high influence on event organization. For this purpose, in this research, it was applied the focus group [45] technique with event managers. This allowed to create an environment that would bring up the opinions, feelings, perceptions, and expectations of experts about the applicability of the proposed model for the Evaluation of Events. As stated by Morgan [45], it allowed interaction in the group discussion, recognizing the active role of the researcher in stimulating the group's discussion for the purposes of data collection. Thus, as stated by Krueger and Casey [46], this focus group explores the subjective perceptions of the interviewees (their needs, interests, concerns) instead of the objective world of the measured behaviour. Focus groups allowed to see not only what people think, but how they think, and it also allowed the collection of qualitative data from people with some kind of similarity, in a group situation, through a focused and complementary discussion. 
There are some limitations to the application of this method, as referred by Smithson [47], due to the possibility of interference of social interaction behaviours like a dominant voice, or normative discourses aligned with what can be usually expected. The interviewer was aware of these possibilities although they were not identified during the focus group. Additionally, as in other qualitative approaches, the number of participants (four) was low and for that reason the results cannot be generalized. But this group was selected because the participants were key informants from the required stakeholders for this research, and allowed to deepen their perceptions about the development of quality instruments for measuring the environmental sustainability of the events, considering the events' participants voices.

\section{Environmental Sustainability Dimension Adapted to the ServQual}

The "Environmental Sustainability" was inserted in the ServQual Model, considering the sustainability dimensions proposed by Ahmad et al. [43] and one more, which this paper comes to consider, the $\mathrm{CO}_{2}$ Emission. This is stated in relation to the customer's expectation as shown in Table 3 . Thus, the following set of statements is related to the degree of expectation that the participant has in relation to the service provider of a public event. It should show how much you think a public event should have of the features described in each environmental sustainability statement.

Table 3. Proposed Dimension—Environmental Sustainability—Expectation.

\begin{tabular}{|c|c|c|}
\hline Dimension & $\mathrm{N}^{\mathbf{o}}$ & Item \\
\hline \multirow{6}{*}{$\begin{array}{l}\text { Environmental } \\
\text { Sustainability }\end{array}$} & 25 & $\begin{array}{l}\text { The service provider is expected to provide services considering } \\
\text { efficient energy consumption. }\end{array}$ \\
\hline & 26 & $\begin{array}{l}\text { The service provider is expected to provide services considering } \\
\text { efficient water consumption. }\end{array}$ \\
\hline & 27 & $\begin{array}{l}\text { The service provider is expected to provide services considering waste } \\
\text { prevention and non-generation, aiming to save natural resources and } \\
\text { contain waste (to reduce, to reuse, and to recycle). }\end{array}$ \\
\hline & 28 & $\begin{array}{l}\text { The service provider is expected to hire suppliers (products/services), } \\
\text { considering its environmental responsibilities. }\end{array}$ \\
\hline & 29 & $\begin{array}{c}\text { It is expected that the service provider will consider communication via } \\
\text { a more sustainable means, and also consider the environmental } \\
\text { education of customers and employees. }\end{array}$ \\
\hline & 30 & $\begin{array}{l}\text { The service provider is expected to use, encourage, and provide means } \\
\text { to reduce } \mathrm{CO}_{2} \text { emissions. }\end{array}$ \\
\hline
\end{tabular}

If the participant strongly agrees with the statement, they should choose 7 and if they strongly disagree, they should choose 1 . If the participant does not strongly agree, neither strongly disagree, it should choose an intermediate level between 2 and 6 . There are no right or wrong answers, because all that matters is a number that best demonstrates expectations about the service provided.

This part refers to the questionnaire that must be applied before the event takes place, so that one can know the participants' expectations regarding the event.

The set of statements described in Table 4 relates to the participant's perception of the event in question, in view of the expectation for the provision of the service. For each statement, as usual in ServQual the participant should choose a level of agreement between 1 and 7 with each statement. Again, there are no right or wrong answers, all that is needed is a number that best shows the participant's perceptions about the event. 
Table 4. Proposed Dimension-Environmental Sustainability-Perception.

\begin{tabular}{|c|c|c|}
\hline Dimension & $\mathrm{N}^{\mathbf{o}}$ & Item \\
\hline \multirow{6}{*}{$\begin{array}{l}\text { Environmental } \\
\text { Sustainability }\end{array}$} & 25 & $\begin{array}{l}\text { The service provider organized the event considering the generation/or } \\
\text { efficient consumption of energy. }\end{array}$ \\
\hline & 26 & $\begin{array}{l}\text { The service provider organized the event considering the efficient } \\
\text { generation and/or consumption of water. }\end{array}$ \\
\hline & 27 & $\begin{array}{l}\text { The service provider organized the event considering the prevention } \\
\text { and non-generation of waste, aiming to save natural resources and } \\
\text { contain waste (to reduce, to reuse, and to recycle). }\end{array}$ \\
\hline & 28 & $\begin{array}{l}\text { The service provider hired suppliers (products/services), considering } \\
\text { their environmental responsibilities. }\end{array}$ \\
\hline & 29 & $\begin{array}{l}\text { The service provider organized the event considering communication } \\
\text { via a more sustainable means of communication, also considering the } \\
\text { environmental education of the participants and the work team. }\end{array}$ \\
\hline & 30 & $\begin{array}{l}\text { The service provider, to organize the event, uses, encourages, } \\
\text { and provides means to reduce } \mathrm{CO}_{2} \text { emissions. }\end{array}$ \\
\hline
\end{tabular}

This part refers to the questionnaire that must be applied after the event happens, so that the participant's perception of the event can be known. "Environmental Sustainability" was inserted in the ServQual Model, in relation to the customer's perception, according to Table 4.

\section{Application of the Adapted ServQual to Events}

In order to verify the applicability and usefulness of the ServQual as a tool for assessment of quality of an event and additionally to assess the inclusion of the new environmental dimension in ServQual, the instrument was applied in three small events in the city of Vitoria: an academic, a cultural/social event, and a sports event.

The result of the data collected in the research, presented and analysed here, was calculated by means of the difference between the customer's perception and expectation, relative to each item of the six dimensions of the ServQual scale, including the proposed new Environmental Sustainability dimension. To perform the calculations, the average of each item for each dimension was calculated, both for expectations and for perceptions of the participants of the event. The ServQual gap value is equal to the subtraction between perception and expectation for each item. All questionnaires followed the ServQual dimensions and items:

- Tangibles: Equipment, physical facilities, appearance of employees and accessibility.

- Reliability: Compliance with deadlines, interest in helping, correct execution, serving as agreed and service execution.

- Response Capacity: goodwill, prompt service, and willingness to answer questions from customers.

- Assurance: Security in transactions with the service provider, certification with given deadlines, and whether the behaviour of employees inspires trust for customers.

- Empathy: Courtesy with customers, employees' ability to answer all questions of services to the customer, individual attention offered by the company to customers, convenience of the service provider opening hours, individual attention offered by employees to customers, the service provider focus on offering the best customer service and the ability to understand its customers' specific needs.

Additionally, the quality model implemented the dimension "Environmental Sustainability" with assertions described previously and related to: Consideration of efficient energy consumption; consideration of efficient water consumption; consideration of prevention and non-generation of waste, aiming to save natural resources and contain waste; consideration in contracting suppliers (products/services), taking into account their environmental responsibilities; communication via a more 
sustainable medium that also considers the environmental education of customers and employees, and provide means to reduce $\mathrm{CO}_{2}$ emissions.

Table 5 shows the results from the application of ServQual in the Academic Event (E1), Cultural Event (E2), and Sports Event (E3). The results are grouped into Expectation and Perception of the public in relation to the events in question. The gap between expectation and perception are presented.

Table 5. Evaluation of the Event Tangibles.

\begin{tabular}{|c|c|c|c|c|c|c|c|c|c|c|}
\hline Dimension & Items & \multicolumn{3}{|c|}{ Expectation } & \multicolumn{3}{|c|}{ Perception } & \multicolumn{3}{|c|}{ Gap } \\
\hline \multirow{4}{*}{ Tangibles } & $\begin{array}{l}\text { The available equipment must be } \\
\text { updated. }\end{array}$ & 5.77 & 5.00 & 6.70 & 5.90 & 5.63 & 6.60 & 0.13 & 0.63 & -0.10 \\
\hline & $\begin{array}{l}\text { The physical facilities of the event } \\
\text { must be visually attractive. }\end{array}$ & 5.54 & 4.88 & 6.80 & 5.80 & 5.38 & 6.30 & 0.26 & 0.50 & -0.50 \\
\hline & $\begin{array}{l}\text { The appearance of the physical } \\
\text { facilities must be consistent with } \\
\text { the service provided. }\end{array}$ & 5.69 & 5.00 & 7.00 & 5.80 & 5.75 & 6.60 & 0.11 & 0.75 & -0.80 \\
\hline & $\begin{array}{l}\text { The organizing team must provide } \\
\text { an event in a location accessible to } \\
\text { its target audience. }\end{array}$ & 6.31 & 5.13 & 7.40 & 5.80 & 5.63 & 6.60 & -0.51 & 0.50 & -0.40 \\
\hline
\end{tabular}

In the Tangible dimension, most items were attended by the service provider (at events E1 and E2), with emphasis on the infrastructure and presentation of the work team. However, at the E3 event, the participants' expectations exceeded their perception of the event.

In the Reliability dimension, any perception item meets the expectation of the participants, compromising the participants' trust in relation to the service provider. Although the difference between perception and expectation is not so high, it is a point to be considered, as the lack of trust is a factor that damages the relationship between the parties. The data can be seen in Table 6 .

Table 6. Evaluation of Event Reliability.

\begin{tabular}{|c|c|c|c|c|c|c|c|c|c|c|}
\hline Dimension & Items & \multicolumn{3}{|c|}{ Expectation } & \multicolumn{3}{|c|}{ Perception } & \multicolumn{3}{|c|}{ Gap } \\
\hline \multirow{4}{*}{ Reliability } & $\begin{array}{l}\text { When a service provider promises } \\
\text { to hold an event on time, they } \\
\text { must follow it. }\end{array}$ & 6.23 & 5.38 & 6.90 & 5.90 & 4.75 & 7.00 & -0.33 & -0.63 & 0.10 \\
\hline & $\begin{array}{l}\text { When participants have problems, } \\
\text { the service provider must } \\
\text { be helpful. }\end{array}$ & 5.92 & 4.75 & 7.00 & 5.60 & 5.0 & 6.30 & -0.32 & 0.25 & -0.70 \\
\hline & $\begin{array}{l}\text { The service provider must } \\
\text { be reliable. }\end{array}$ & 6.31 & 5.50 & 7.00 & 6.10 & 5.13 & 6.40 & -0.21 & -0.37 & -0.60 \\
\hline & $\begin{array}{l}\text { The provider must provide their } \\
\text { services at the time they promise } \\
\text { to do so. }\end{array}$ & 5.92 & 5.00 & 6.90 & 5.60 & 4.75 & 5.80 & -0.32 & -0.25 & -1.10 \\
\hline
\end{tabular}

In terms of Responsiveness, the events E1 and E2 proved to be of quality. All the points assessed met the expectations of the participants. In this item, this is very positive, as the participants were well attended and there was a concern to do the best to meet the requests of the participants. The data can be seen in Table 7. 
Table 7. Evaluation of the Event Responsiveness.

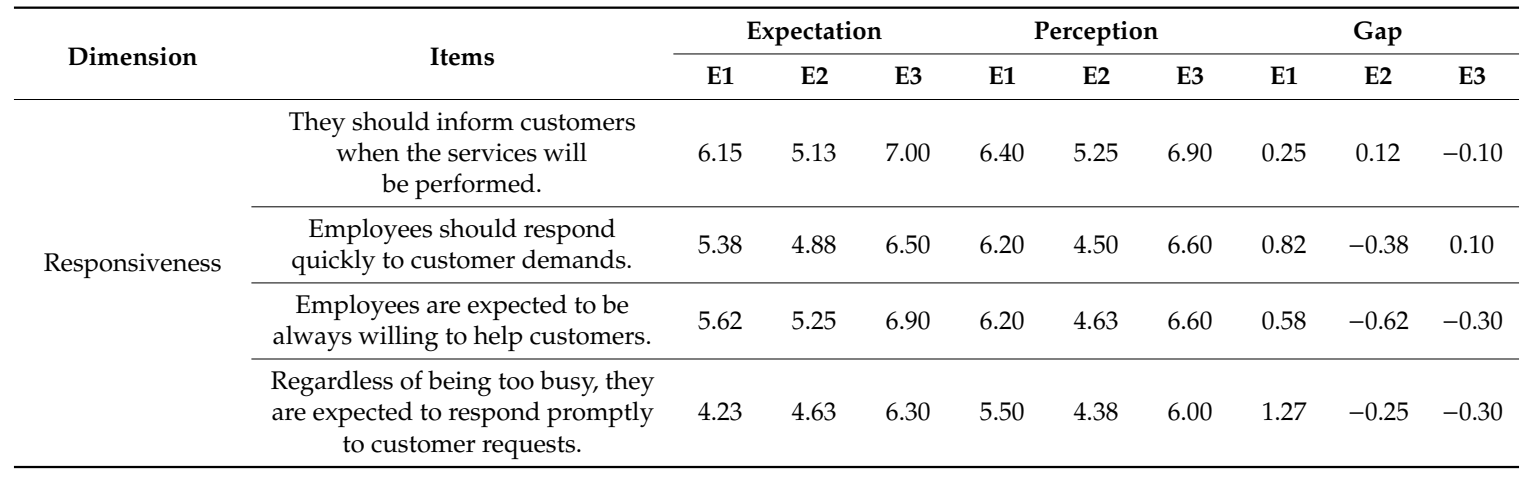

In the case of the Assurance of the events, that is, how secure it feels in carrying out a transaction with the supplier of the event, all points were negative except for politeness and kindness of employees at E3. The event participant's expectation was higher than the perceived, and this implies an unsuccessful experience. The data can be seen in Table 8.

Table 8. Evaluation of the Event Assurance.

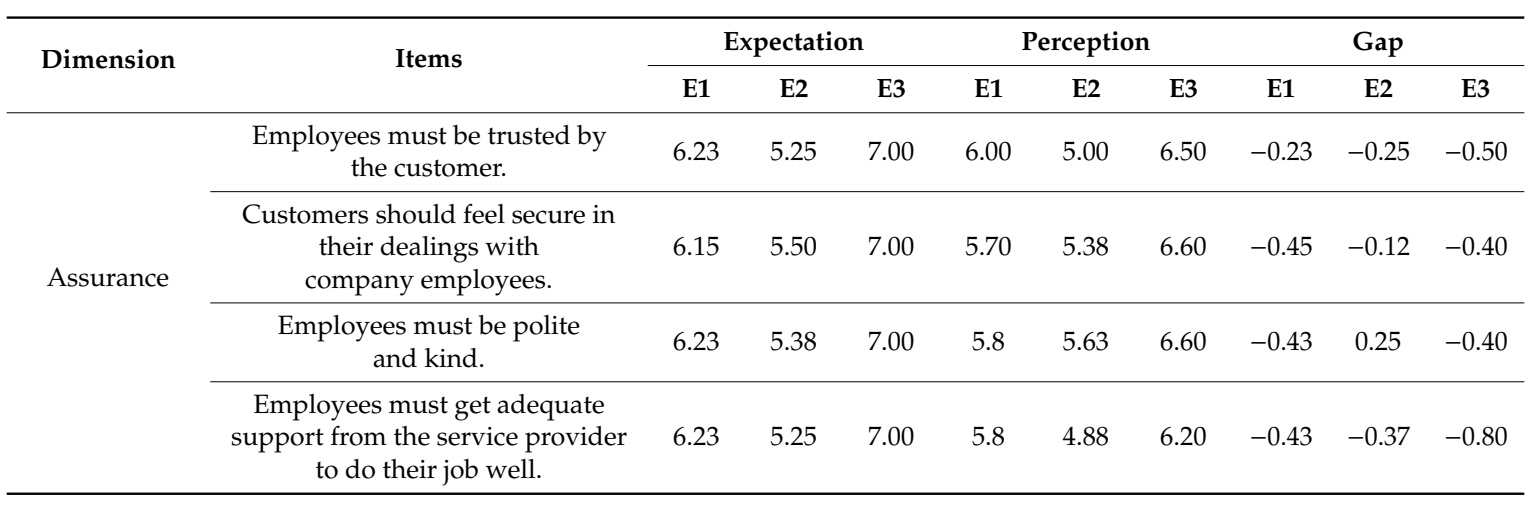

Regarding Empathy, it can be seen that there was a good experience felt by the client. Despite not being confident and not feeling safe, the participants of the event had due attention, their interests were well attended and prioritized, and had individualized service. The data can be seen in Table 9.

Table 9. Assessment of Event Empathy.

\begin{tabular}{|c|c|c|c|c|c|c|c|c|c|c|}
\hline \multirow{2}{*}{ Dimension } & \multirow{2}{*}{ Items } & \multicolumn{3}{|c|}{ Expectation } & \multicolumn{3}{|c|}{ Perception } & \multicolumn{3}{|c|}{ Gap } \\
\hline & & E1 & E2 & E3 & E1 & E2 & E3 & E1 & E2 & E3 \\
\hline \multirow{4}{*}{ Empathy } & $\begin{array}{l}\text { The service provider is expected to } \\
\text { give personalized attention } \\
\text { to customers. }\end{array}$ & 3.62 & 4.63 & 5.90 & 5.10 & 4.50 & 6.20 & 1.48 & -0.13 & 0.30 \\
\hline & $\begin{array}{l}\text { Employees are expected to give } \\
\text { personalized attention } \\
\text { to customers. }\end{array}$ & 3.54 & 4.50 & 6.40 & 5.10 & 4.63 & 5.10 & 1.56 & 0.13 & -0.13 \\
\hline & $\begin{array}{l}\text { Employees are expected to know } \\
\text { what their customers' needs are. }\end{array}$ & 4.23 & 4.75 & 6.60 & 5.50 & 4.38 & 5.60 & 1.27 & -0.37 & -1.00 \\
\hline & $\begin{array}{l}\text { The service provider is expected to } \\
\text { prioritize the interests of } \\
\text { their customers. }\end{array}$ & 3.85 & 4.13 & 6.50 & 4.50 & 4.63 & 5.50 & 0.65 & 0.50 & -1.00 \\
\hline
\end{tabular}


Finally, in relation to Environmental Sustainability, three points were negative: the concern with waste, the contracting of suppliers, and sustainable communication. Issues related to water and energy are considered positive. It should be noted here that the events were held by organizations that have an environmental concern. We can also see that the participants' expectations regarding the reduction of $\mathrm{CO}_{2}$ emissions were very low. The data can be seen in Table 10 .

Table 10. Evaluation of the Event's Environmental Sustainability.

\begin{tabular}{|c|c|c|c|c|c|c|c|c|c|c|}
\hline Dimension & Items & \multicolumn{3}{|c|}{ Expectation } & \multicolumn{3}{|c|}{ Perception } & \multicolumn{3}{|c|}{ Gap } \\
\hline \multirow{5}{*}{$\begin{array}{l}\text { Environmental } \\
\text { Sustainability }\end{array}$} & $\begin{array}{l}\text { The service provider is expected to } \\
\text { provide services considering } \\
\text { efficient energy consumption. }\end{array}$ & 3.46 & 5.13 & 6.60 & 4.20 & 4.88 & 6.50 & 0.74 & -0.25 & -0.10 \\
\hline & $\begin{array}{l}\text { The service provider is expected to } \\
\text { provide services considering } \\
\text { efficient water consumption. }\end{array}$ & 4.08 & 5.25 & 6.80 & 4.20 & 4.63 & 5.10 & 0.12 & -0.62 & -1.70 \\
\hline & $\begin{array}{l}\text { The service provider is expected to } \\
\text { provide services considering waste } \\
\text { prevention and non-generation, } \\
\text { aiming to save natural resources } \\
\text { and contain waste (to reduce, to } \\
\text { reuse, and to recycle). }\end{array}$ & 4.08 & 5.25 & 6.90 & 4.00 & 3.63 & 3.60 & -0.08 & -1.62 & -3.30 \\
\hline & $\begin{array}{l}\text { It is expected that the service } \\
\text { provider will consider } \\
\text { communication via a more } \\
\text { sustainable means, and also } \\
\text { consider the environmental } \\
\text { education of customers } \\
\text { and employees. }\end{array}$ & 4.38 & 4.88 & 6.70 & 4.20 & 5.0 & 5.90 & -0.18 & 0.12 & -0.80 \\
\hline & $\begin{array}{l}\text { The service provider is expected to } \\
\text { use, encourage, and provide } \\
\text { means to reduce } \mathrm{CO}_{2} \text { emissions. }\end{array}$ & 2.77 & 4.63 & 6.40 & 2.90 & 3.75 & 4.40 & 0.13 & -0.88 & -2.00 \\
\hline
\end{tabular}

This item aimed to assess the use of ServQual, with the inclusion of the Environmental Sustainability dimension, as to its applicability and usefulness. For that, ServQual was used to evaluate the quality of the selected events, in which the dimensions of the quality expected and the quality perceived by the participants were measured and analysed, and as it could be verified it was possible to use the model for evaluation of the event quality. Despite the low number of responses, it was possible to verify the model applicability in three events with distinct characteristics, and to make some additional analysis on the managerial implications and, thus, reinforce the utility of the model.

\subsection{Gender Perspective}

Some gender differences stand out in the data analysis, as represented in the graph of Figure 1. Female respondents revealed to be more concerned with "Responsiveness" and "Environmental Sustainability," while the male respondents stand out in concern with "Assurance". The gaps for "Reliability" and "Empathy" are more similar across gender. Remarkably, female respondents were particularly dissatisfied with the service considering the new proposed dimension for "Environmental sustainability." 


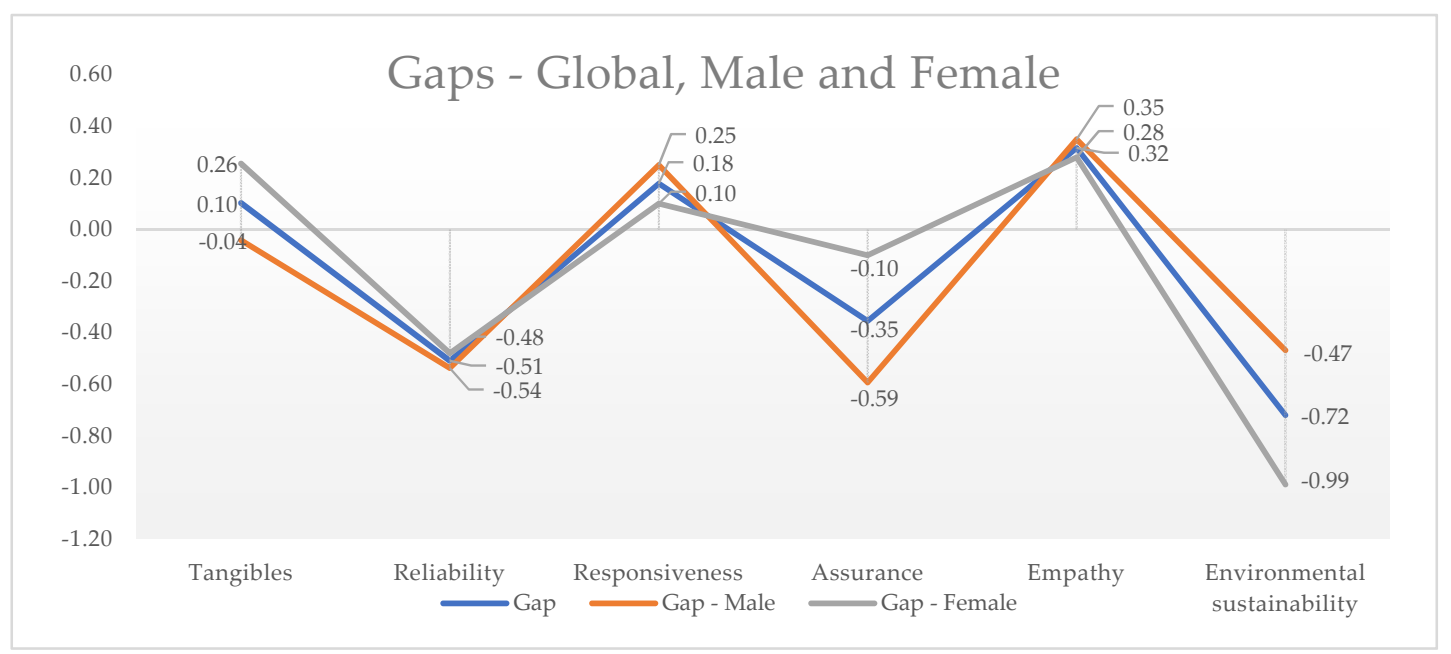

Figure 1. Analysis of gaps considering a gender perspective.

\subsection{Importance-Performance Analysis}

Importance-performance analysis (IPA) is a popular approach for interpreting customer satisfaction and for setting up priorities for upgrading service quality, which was proposed by Martilla and James [48]. IPA builds on customers' assessments concerning the importance and the performance of quality attributes in order to diagnose areas for improvement, typically using data collected by means of questionnaires employing service scales. IPA offers a plot representation for the measurements for importance-performance, declared by customers, consisting of a four quadrants matrix. The IPA matrix plots these values against two axes: a vertical axis, for the values of importance of service attributes; and an horizontal axis, for the values of attribute performance (see Figure 2). IPA allows for a concise display of data and enables the quick visual identification of what elements demand for managerial improvement actions (i.e., attributes ranked in the quadrant for high importance vs. low performance) as well as others where the providers efforts are potentially misplaced (i.e., attributes ranked in the quadrant for low (customer) importance vs. high (provider) performance).

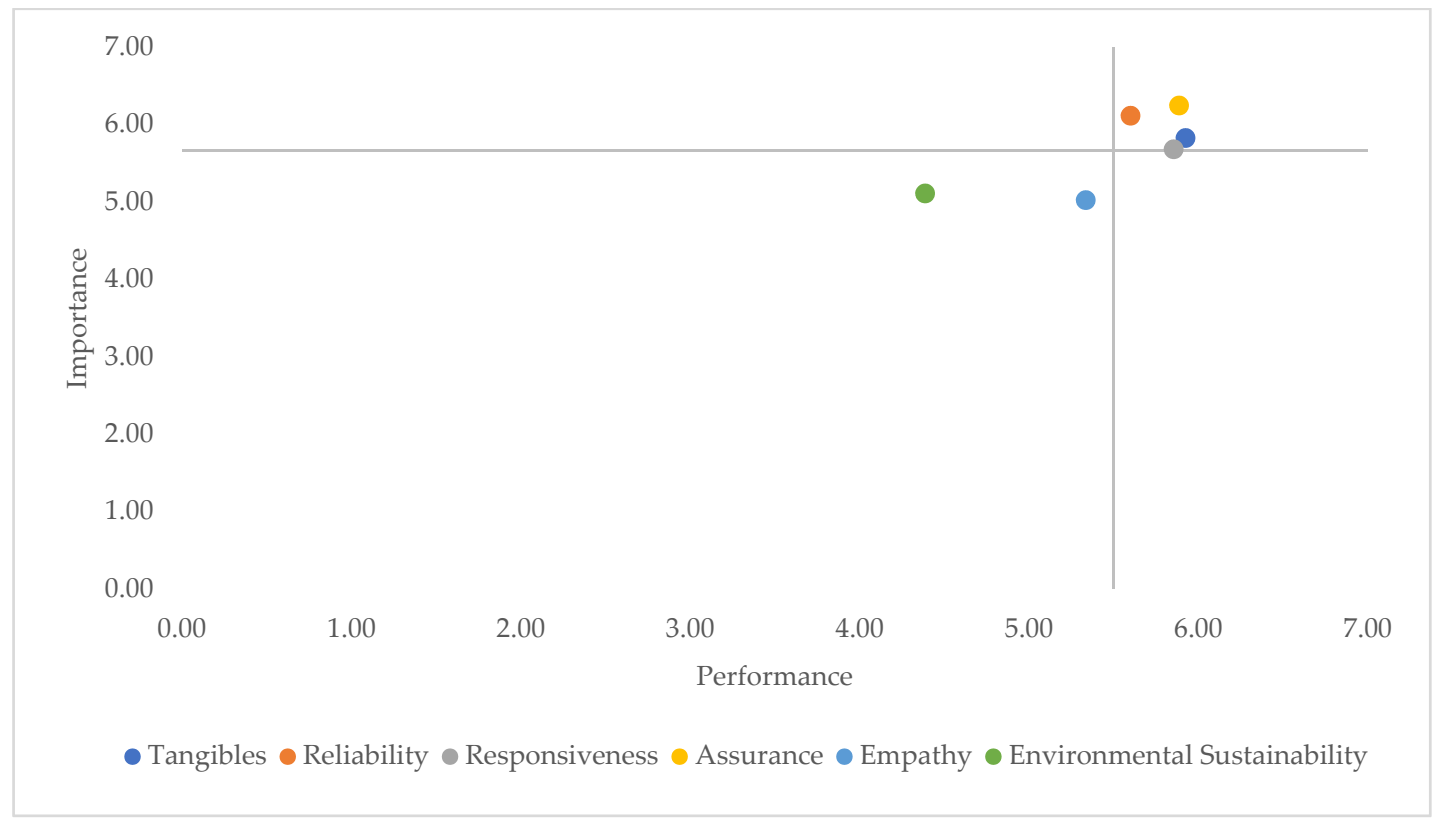

Figure 2. Importance-Performance Analysis. 
The analysis of the graph shows four of the service quality dimensions considered in this study are positioned in the quadrant for high importance/high performance (tangibles, assurance, reliability, and responsiveness); and the two remaining dimensions in the quadrant low importance/low performance (empathy and environmental sustainability). These results suggest for the context of event services, the proposed dimension of environmental sustainability, is both not yet regarded as important by customers, and also less well evaluated by them. An important conclusion from this analysis is the need to work on the importance/visibility of the actions taken by the service provider in this domain.

The study also investigated the existence of differences in customers' expectations and quality perceptions across the different types of events (academic, social/cultural, and sports) for the specific dimension of environmental sustainability. Data analysis evidenced that customers hold higher levels of expectations for environmental sustainability for sports events as compared to social/cultural and academic events. Likewise, perceptions about the performance concerning the management of environmental sustainability are also higher for sports, followed by academic and social/cultural events. These results open avenues for more research in order to understand the root causes of such differences, notably if they stem from distinct characteristics (e.g., environmental awareness) of the corresponding customers, or rather it they are reflecting differences in environmental practices across distinct types of events.

\section{Evaluation of the Adapted ServQual Applied to Events}

In order to assess the inclusion of the new dimension of environmental sustainability in ServQual, the second step was the creation of a Focus Group with four event managers in the Municipality of Vitoria, State of Espírito Santo, Brazil. These managers work in the following areas: Social Events (Participant 1), Sporting Events (Participant 2), Business Events (Participant 3), and Wedding Events (Participant 4).

At first, the objective of the investigation and the objective of the Focus Group were presented to the group. Subsequently, the group responded to a set of open questions, which aimed to validate the insertion of the Event Quality assessment, considering environmental sustainability as a new dimension.

The ServQual Service Evaluation scale was presented, and the importance of having a comparison between the customer's expectation and perception, in order to have a better evaluation. They were unanimous in saying that they never thought quality evaluation from this point of view, and considered it extremely important to seek the requirements that customers expect, and not only what they perceived as they usually did, as it can be seen in the following statements:

"I think that your talk about the quality of the event is very interesting. Usually we only care about checking what the people thought of the event ... but seeing on the other hand, knowing what she expects from the event can show me beforehand what I can do to surprise." (Participant 2)

"I never thought about it. Everything is always so busy! But yes ... I agree that it is important to help you know what the client's requirements are." (Participant 3)

Regarding the Environmental Sustainability dimension, the participants were unanimous in highlighting sustainability as a quality characteristic of an event. Nevertheless, they agreed among themselves that it may be difficult to apply this dimension in their own events, because the participants may not have this focus. This can be seen in the following statements, which are in line with one of the conclusions taken from the IPA analysis at the end of the previous section.

"This is very true! Our corporate customers already have this concern, if only to comply with certain laws. I still see a lot of complaints from them ... they think they spend more to be able to fullfill. They don't really see the importance yet." (Participant 3) 
"We do, but we still leave a lot to be desired. I think it is very important, because we are highly demanded by society. When the races are over, no one wants to see the streets dirty with plastic bottles, fruit scraps. It wasn't like that. It's been about 6 years ago that this request has increased. We need to improve a lot, we haven't explored that much yet, but it is because we are fixed in the event, in working out you know." (Participant 2).

A question was also raised about sustainability in events from the point of view of the user of the service provided: does the event participant really know what sustainability is? If participants are not aware of it, they do not generate expectations in relation to the environmental sustainability of an event and they may not even know how to evaluate the existence of sustainable actions in the events, as shown in the following statements:

"Look ... being very sincere with you ... (laughter), until today only one bride wanted the wedding in a format with a footprint more like this, and it was very difficult for our team, which was not used to this idea. Brides mainly want to show others what they have and what they don't have. The idea is that nobody leaves the event complaining about anything, so they spend a lot. But I already see this idea in non-wedding events, as in companies' events, like at the end of the year of these wedding suppliers they already want to show their customers and employees that they are concerned about it." (Participant 4)

Thus, it seems that there is a need to raise awareness among the population, service providers, and their employees, as well as suppliers, stakeholders, and the entire supply chain of an event.

In conclusion, from the realization of the focus group, it was also possible to perceive the managerial usefulness of the model for the participants. In addition, it was clear that this focus group also raised the opportunity to increase the awareness about the importance of measuring the quality of events, applying a systematic model, as well as of spreading the need to manage environmental sustainability.

\section{Conclusions}

This research, started from the perspective that event management shares many characteristics of services and, as such, extends the application of service management tools to the specific domain of events. A starting point was to understand that it is possible to develop existing models to measure the quality of the service considering environmental sustainability. The study was based on the existing models of quality of service, in order to integrate new dimensions that capture the assessment of customers on sustainability attributes in the context of events.

The present study answers the research question on how to measure the quality of the event from the expectations and perceptions of the event participant, considering that in this type of service, the user is a key player. This was due to adaptations of the ServQual Scale for events, as well as the inclusion of the Environmental Sustainability dimension. This inclusion suggests environmental sustainability as a quality characteristic of events, and therefore subject to evaluation in terms of quality, by the participants of the events. The insertion of environmental sustainability highlights its importance as a value generator for the client.

The model proposed in this paper seeks to develop a focus on the client/participant of the event, the team, and the place that receives the event, in addition to instigating the importance of stakeholder participation and event participants in the event's sustainability issues, creating a sense of responsibility and awareness.

As future work, we recommend expanding the research to events of other types and dimensions, as well as expanding the study to a larger number of events. In addition, this could be considered a starting point for other studies that could be dedicated to the statistical validation of the proposed new dimension. In terms of quality assurance, it would be feasible to expand the application of ServQual, proposed in this paper, to all stakeholders, such as residents, in order to better understand their quality requirements. We also see the usefulness of research aimed at the inclusion of technologies in events, 
immersive experiences, new protocols, and impacts on the quality and sustainability of events, as well as on the expectations of quality on the part of stakeholders, participants and the local community, considering a post-Covid-19 world.

Author Contributions: Conceptualization, R.M.L. and A.M.; methodology, A.M. and R.M.L.; validation, A.L.A.; formal analysis, A.M., A.L.A. and M.A.; investigation, A.M.; writing-original draft preparation, A.M. and R.M.L.; writing-review and editing, A.M., R.M.L., A.L.A. and M.A.; visualization, M.A.; supervision, R.M.L. and A.L.A. All authors have read and agreed to the published version of the manuscript.

Funding: This work was partially supported by FCT-Fundação para a Ciência e Tecnologia within the R\&D Units Project Scope UIDB/00319/2020, and by CAPES—Coordenação de Aperfeiçoamento de Pessoal de Nível Superior (Coordination of Superior Level Staff Improvement) within the Science without Borders Program Scope.

Conflicts of Interest: The authors declare no conflict of interest.

\section{References}

1. De Brito, M.; Terzieva, L. Key elements for designing a strategy to generate social and environmental value: A comparative study of festivals. Res. Hosp. Manag. 2016, 6, 51-59. [CrossRef]

2. Allen, J.; O'Toole, W.; Harris, R.; McDonnell, I. Festival and Special Event Management, 5th ed.; Wiley \& Sons: Milton, Australia, 2011.

3. Turner, Z.; Kennell, J. The Role of Sustainable Events in the Management of Historic Buildings. Sustainability 2018, 10, 3884. [CrossRef]

4. Collins, A.; Potoglou, D. Factors influencing visitor travel to festivals: Challenges in encouraging sustainable travel. J. Sustain. Tour. 2019, 27, 668-688. [CrossRef]

5. Kişi, N. A Strategic Approach to Sustainable Tourism Development Using the A'WOT Hybrid Method: A Case Study of Zonguldak, Turkey. Sustainability 2019, 11, 964. [CrossRef]

6. Shone, A.; Parry, B. Successful Event Management-A Pratical Handbook, 4th ed.; Cengage Learning: Andover, MA, USA; Hampshire, UK, 2013; p. 6.

7. Eighth Annual Meetings and Events Trends Report 2019; CWT: Minneapolis, MI, USA, 2019.

8. AMR. Global Opportunity Analysis and Industry Forecast 2019-2026. Allied Market Research. Available online: https://www.alliedmarketresearch.com/events-industry-market (accessed on 31 July 2020).

9. Mair, J.; Whitford, M. An exploration of events research: Event topics, themes and emerging trends. Int. J. Event Festiv. Manag. 2013, 4, 6-30. [CrossRef]

10. Gallagher, A.; Pike, K. Sustainable Management for Maritime Events and Festivals. J. Coast. Res. 2011, 61, 158-165. [CrossRef]

11. Chesbrough, H.; Spohrer, J. A research manifesto for services science. Commun. ACM 2006, 49, 35-40. [CrossRef]

12. Heizer, J.; Render, B. Operations Management, 7th ed.; Prentice Hall: Upper Saddle River, NJ, USA, 2004.

13. Sampson, S.E. The unified service theory: A paradigm for service science. In Handbook of Service Science; Maglio, P.P., Kieliszewski, C., Spohrer, J.C., Eds.; Springer: New York, NY, USA, 2010; pp. 107-131.

14. Sampson, S.; Froehle, C. Foundations and Implications of a Proposed Unified Services Theory. Prod. Oper. Manag. 2006, 15, 329-343. [CrossRef]

15. Amorim, M.; Moscoso, P.; Lago, A. Customer participation in services: A framework for process Design. Int. J. Qual. Res. Serv. 2015, 2, 47-61. [CrossRef]

16. Zeithaml, V.A.; Bitner, M.J.; Gremler, D.D. Marketing de Serviços—A Empresa com Foco no Cliente, 6th ed.; Amgh Editora: Porto Alegre, Rio Grande do Sul, Brazil, 2014.

17. Dowell, D.; Garrod, B.; Turner, J. Understanding value creation and word-of-mouth behaviour at cultural events. Serv. Ind. J. 2019, 39, 498-518. [CrossRef]

18. Ding, Y.; Keh, H.T. Consumer reliance on intangible versus tangible attributes in service evaluation: The role of construal level. J. Acad. Mark. Sci. 2017, 45, 848-865. [CrossRef]

19. Koc, E.; Ulukoy, M.; Kilic, R.; Yumusak, S.; Bahar, R. The influence of customer participation on service failure perceptions. Total Qual. Manag. Bus. Excell. 2017, 28, 390-404. [CrossRef]

20. Guo, X.; Dong, Y.; Ling, L. Customer perspective on overbooking: The failure of customers to enjoy their reserved services, accidental or intended? J. Air Transp. Manag. 2016, 53, 65-72. [CrossRef] 
21. Bitran, G.; Lojo, M. A framework for analyzing the quality of the customer interface. Eur. Manag. J. 1993, 11, 271-282. [CrossRef]

22. Parasuraman, A.; Zeithaml, V.A.; Berry, L.L. A Conceptual Model of Service Quality and Its Implications for Future Research. J. Mark. 1985, 49, 41-50. [CrossRef]

23. Armbrecht, J. An event quality scale for participatory running events. Event Manag. 2020, 24, 139-152. [CrossRef]

24. Biscaia, R.; Correia, A.; Santos, T.; Ross, S.; Yoshida, M. Service quality and value perceptions of the 2014 FIFA World Cup in Brazil. Event Manag. 2017, 21, 201-216. [CrossRef]

25. Richards, G. Measuring the dimensions of event experiences: Applying the Event Experience Scale to cultural events. J. Policy Res. Tour. Leis. Events 2019. [CrossRef]

26. Pelissari, A.; Solis, D.; Ianagui, E.; Gonzalez, I.; Setubal, F. Application and Assessment of the Servqual Model to Analyze the Quality of the Service. InterSciencePlace 2012, 1. [CrossRef]

27. Valencia-Arias, A.; Piedrahita, L.; Zapata, A.; Benjumea, M.E.; Moya, L. Mapping the healthcare service quality domain: A bibliometric analysis. J. Clin. Diagn. Res. 2018, 12, IC01-IC05. [CrossRef]

28. Slack, N.; Stuart, C.; Johnston, R.; Betts, A. Administração da Produção, 3rd ed.; Atlas: São Paulo, Brazil, 2009; p. 703.

29. Fitzsimmons, J.A.; Fitzsimmons, M. Administração de Serviços: Operações, Estratégia e Tecnologia Da Informação, 6th ed.; Bookman: Porto Alegre, Brazil, 2010.

30. Wang, M.C.-H. Determinants and consequences of consumer satisfaction with self-service technology in a retail setting. Manag. Serv. Qual. 2012, 22, 128-144. [CrossRef]

31. Ameryoun, A.; Seyedvahid, N.; Nejati-Zarnaqi, B.; Khalilifar, S.; Ajam, M.; Ansarimoghadam, A. Factor selection for service quality evaluation: A hospital case study. Int. J. Health Care Qual. Assur. 2017. [CrossRef] [PubMed]

32. Midor, K.; Kučera, M. Improving the Service with the ServQualMethod. Manag. Syst. Prod. Eng. 2017, 26. [CrossRef]

33. Brown, S.; Getz, D.; Pettersson, R.E.; Wallstam, M. Event evaluation: Definitions, concepts and a state of the art review. Int. J. Event Festiv. Manag. 2015, 6, 135-157. [CrossRef]

34. Jaimangal-Jones, D.; Fry, J.; Chaven-Tang, C. Exploring industry priorities regarding customer satisfaction and implications for event evaluation. Int. J. Event Festiv. Manag. 2018, 9. [CrossRef]

35. Kowalik, K.; Klimecka-Tatar, D. The process approach to service quality management. Prod. Eng. Arch. 2017, 18, 31-34. [CrossRef]

36. Jin, N.; Lee, H.; Lee, S. Event quality, perceived value, destination image, and behavioral intention of sports events: The case of the "IAAF World Championship, Daegu, 2011". Asia Pac. J. Tour. Res. 2013, 18, 849-864. [CrossRef]

37. Meleddu, M.; Melis, G.; Pulina, M.; Zapata-Aguirre, S. Expectations and service quality: Perceived performance at low-season events. Int. J. Event Festiv. Manag. 2019, 10, 110-137. [CrossRef]

38. An, B.; Harada, M.; Sato, S. Service quality, satisfaction, and behavioral intention in a triathlon event: The different experiences between local and non-local participants. J. Sport Tour. 2020. [CrossRef]

39. Boggia, A.; Massei, G.; Paolotti, L.; Rocchi, L.; Schiavi, F. A model for measuring the environmental sustainability of events. J. Environ. Manag. 2018, 206, 836-845. [CrossRef]

40. Pelham, F. Will sustainability change the business model of the event industry? Worldw. Hosp. Tour. Themes 2011, 3, 187-192. [CrossRef]

41. Negruşa, A.; Toader, V.; Rus, R.; Cosma, S. Study of Perceptions on Cultural Events' Sustainability. Sustainability 2016, 8, 1269. [CrossRef]

42. Aguiar-Quintana, T. Under-researched Areas of Event Management in the Past 15 Years. J. Tour. Hosp. 2015, 4, 160. [CrossRef]

43. Ahmad, N.L.; Rashid, W.E.; Razak, N.A.; Yusof, A.N.; Shah, N.S. Green Event Management and Initiatives for Sustainable Business Growth. Int. J. Trade Econ. Financ. 2013, 4. [CrossRef]

44. Gil, A.C. Como Elaborar Projeto de Pesquisa, 5th ed.; Atlas: São Paulo, Brazil, 2010.

45. Morgan, D.L. Focus Group as Qualitative Research, 2nd ed.; Sage: Thousand Oaks, CA, USA, 1997.

46. Krueger, R.; Casey, M.A. Focus Group. A Pratical Guide for Apllied Research, 4th ed.; Sage Publications: Los Angeles, CA, USA, 2009. 
47. Smithson, J. Using and analysing focus groups: Limitations and possibilities. Int. J. Soc. Res. Methodol. 2000, 3, 103-119. [CrossRef]

48. Martilla, J.A.; James, J.C. Importance-performance analysis. J. Mark. 1977, 41, 77-79. [CrossRef]

(C) 2020 by the authors. Licensee MDPI, Basel, Switzerland. This article is an open access article distributed under the terms and conditions of the Creative Commons Attribution (CC BY) license (http://creativecommons.org/licenses/by/4.0/). 